\title{
Evaluation of Environmental Effect of Shiroro Hydropower Dam on the Downstream Communities of Shiroro Local Government Area, Niger State, Nigeria
}

\author{
Anzaku M. Iliyasu ${ }^{1} \quad$ Buba Y. Alfred ${ }^{3} \quad$ Onoja F. Idoko $^{3} \quad$ Alkali Mohammed $^{2} \quad$ Sa'adu Sabitu Da' $^{1}$ \\ 1. School of Continuing Education, Department of Sciences, Bayero University, Kano, Nigeria \\ 2. Department of Environmental Sciences, Nasarawa State University Keffi, Nasarawa State, Nigeria \\ 3. Nigerian Building \& Road Research Institute, 10 NBRRI Road/ I.T. Igbani Street, Jabi District, Abuja, FCT, \\ Nigeria
}

\begin{abstract}
This study evaluates the environmental effect of Shiroro hydropower dam on the downstream communities. The main objective of this study is to investigate the environmental effects of Shiroro hydropower dam on the downstream communities. A suitable conceptual framework was formulated and obtained data on the environmental impacts of dam on downstream communities, followed by a comprehensive literature review for viable information on the study. Three communities were used as case studies and quantitative method was used as an appropriate research paradigm such as structured questionnaire survey (with predominantly quantitative questions) and relevant data was obtained from the study area. Subsequently the data was analysed using descriptive, factor analysis and Kruskal-Wallis test as well construct reliability and validity analysis. From a broad range of environmental impacts, core environmental impacts were determined. The core impacts include changes in riparian vegetation, changes in river water quality, changes to channel shape and changes in floodplains among others. Similarly, control techniques were identified to lessen the effect of the impact and the result revealed that watershed management, water pollution control, management of water releases, fishing regulation, fish hatcheries and fish passage facilities were the core control techniques. The result of Kruskal-Wallis test revealed that majority of the environmental impacts affecting the communities under study is significantly and statistically different while the Cronbach alpha for internal consistencies of the constructs of the questionnaire was 0.745 , hence high enough for generalising the result.
\end{abstract}

Keywords: Environment, Effects, Hydroelectric, Dam, Downstream

DOI: $10.7176 / \mathrm{JEES} / 9-3-11$

Publication date:March $31^{\text {st }} 2019$

\subsection{INTRODUCTION}

Rivers have played a key role in shaping the earth's physical and ecological landscapes through their distinctive hydrologic characteristics, as well as shaping cultural landscapes by providing food, water, and other ecosystem services. However, with the rise of ancient civilizations came a rise in building dams and diversions for water storage, irrigation, flood control and transportation. Accordingly, as early as $6500 \mathrm{BC}$, the Sumerians constructed dams across the Tigris and Euphrates rivers to provide flood control and irrigation for crops (Mc Cully, 2001). By the first millennium BC, however, stone and earthen dams were erected on nearly every continent, enabling the acquisition of water and food to sustain population growth. Furthermore, dam technology advanced slowly until the Industrial Revolution when larger dams were built in less time and from man-made materials (DiFrancesco and Woodruff, 2007).

Moreover, dams; large and small, are planned, constructed and operated to meet human needs in the generation of energy, irrigated agricultural production, flood control, supply of drinking water, and various other purposes (WCD, 2000a). According to McCartney et al., (2001), dams built to change natural flow systems, are one of the most major human interventions in the hydrological cycle. Hence, it became a prominent instrument for economic development in the past century. Worldwide, the number of large dams stood at 5000 in 1950 (ICOLD, 1998); with three quarters of these dams in Europe, North America, and other industrial regions. By 2000, the number of large dams had ascended to over 45,000, and these were spread among more than 140 countries (Duflo and Pande, 2008; ICOLD, 1998). On average, two large dams were built per day for half a century (WCD, 2000) and today, the number of large dams exceeds 50,000 (Berga et al., 2006).

According to the criteria used by the International Committee On Large Dams (ICOLD) a large dam is one that fulfils at least one of the following criteria: higher than $15 \mathrm{~m}$, higher than $10 \mathrm{~m}$ but with a crest length of more than $500 \mathrm{~m}$, has more than $1 \mathrm{Mm} 3$ storage capacity, has more than $2000 \mathrm{~m}^{3} \mathrm{~s}-1$ spilling capacity, has special foundation problems or is of unusual design. It is believed that the world dams have an aggregate storage capacity of about $6,000 \mathrm{~km}^{3}$ (Le Cornu, 1998a) and the construction of dams results in physical, chemical and biological changes to natural ecosystems (McCartney et al., 2001).

In addition, large dams disrupt flow and sediment delivery downstream, thus inducing channel change that 
may extend hundreds of kilometres (Andrews, 1986; Borland and Miller, 1960; Brandt, 2000a; Carling, 1988; Grant et al., 2003; Petts, 1979; Schumm, 1969; Stevens, 1938; Williams and Wolman, 1984). Consequently, some of these channel changes adversely impact cities and towns, agriculture, native riverine ecosystems, and valued landscapes (Grant et al., 2003). Hence, environmental management programs now attempt to reverse some undesired channel changes (WCD, 2000a). However, because these programs require substantial resources; it is appropriate for the scientific community to provide managers and decision makers with tools to evaluate the factors that cause channel change. Better understanding of the factors that drive channel change might provide a rational basis for distributing scarce national resources to the various programs that attempt river rehabilitation (ibid).

Furthermore, the belief that large dams, by increasing irrigation and hydroelectricity production, can cause development and reduce poverty has led developing countries and international agencies such as the World Bank to undertake major investments in dam construction (Grant et al., 2003; WCD, 2000a). By the year 2000, dams generated 19 percent of the world's electricity supply and irrigated over 30 percent of the 271 million hectares irrigated worldwide (McCartney et al., 2001; WCD, 2000a). However, these dams also displaced over 40 million people, altered cropping patterns, and significantly increased salinazation and water logging of aerable land (WCD, 2000a). The distribution of the costs and benefits of large dams across population groups, and, in particular, the extent to which the rural poor have benefited, are issues that remain widely debated.

In terms of Nigeria, Oyebande (1995) stated that about 162 large, medium and small dams have been constructed and are being operated in Nigeria. They have a total storage capacity of more than $30 \times 109 \mathrm{~m} 3$, i.e. less than $10 \%$ of the country's total potential surface water resources (ibid). A sample of 52 dams indicates that $79 \%$ have domestic / industrial water supply components, while $33 \%$ have irrigation as a major use to which the stored water is put; $4 \%$ are also for hydro-electric power generation (HEP); $29 \%$ for fisheries and $16 \%$ for recreation (Oyebande, 1995). All the dams contribute to flood mitigation and affect the area of wetlands (floodplain) in their downstream areas (Graf, 2006).

Though, the operation of hydro power (HP) dams which is one of the uses of dam often leads to environmental and ecological problems (Salami and Sule, 2010). When inflows are low energy output from HP sources is limited. Water may not be released in adequate quantities from the reservoir, a situation that can affect ecological balance of the river below the HP dam (Sule, 2003). On the other hand, discharge from HP dams can entail large water outflow which can cause flooding to adjoining lands downstream of the dam; a situation that occurred last year in Nigeria where almost all the states in middle belt of Nigeria were flooded (Aribisala and Sule, 1998). Consequently, the flood plains become regions of economic, social and agricultural activities extensive damages (ibid). In Nigeria this is particularly so, as the riverbanks are used for farming and are inhabited by farming communities (Olukanni and Sule, 2010). Hence, the operation of HP dams in Nigeria has been based on conventional water release rule instead of using scientific analysis to determine the reservoir regulation policies (Sule, 2003). As a result, improper water release plan is witness in the country (ibid).

In recent times, however, dam construction in developed countries has decreased as a majority of economically sustainable projects have already been pursued. Additionally, changes in ideology and a growing awareness of the environmental and social impacts of dams have become important factors that influence valuations of dam projects in developed countries (Born et al. 1998, Johnson and Graber, 2002). Furthermore, dams that no longer function for their intended purposes or that pose safety hazards have been decommissioned and removed (Katopodis and Aadland, 2006). Nonetheless, the political-ecology dimension of developing countries and the multiple practical benefits provided by dams continue to favour the rise of these structures in regions where the resources offered by free flowing rivers provide incentive for industrial and infrastructure development (Goodland, 1997).

\subsection{The Study Area}

Shiroro Local Government is located on Longitude $6^{\circ} 25^{\prime} \mathrm{E}$ to $6^{\circ} 51^{\prime} \mathrm{E}$ and Latitude $09^{\circ} 58^{\prime} \mathrm{N}$ to $10^{\circ} 02^{\prime} \mathrm{N}$ approximately in Niger State, Nigeria. It has a population of about 24, 000 (Olasehinde, 1999). The Shiroro Local Government Area hosts one of the biggest hydropower dams in Nigeria and there exist a numbers of communities both at the upstream and downstream of Shiroro Dam in Shiroro Local Government Area of Niger State (Figure1, 2 and Plate 1).

Furthermore, the study areas fall within the North-central portion of the Basement Complex rocks of Nigeria which is composed of three lithological units: migmatite-gneiss complex, low grade schist belts and the older granite (McCurry, 1983; Ajibade and Wright, 1988; Olarewaju et al., 1996; Olasehinde, 1999). Consequently, the area is generally low lying with some conspicuous hills and the area is well drained by River Shiroro and its tributaries.

Moreover, the climate of the study areas is typical of Nigeria, having distinct wet and dry season. Humidity is related to movement of ITD. The highest values are recorded during the raining season (about $80 \%$ ), and the lowest values occur in January (approximately30\%). Additionally, the beginning of the rain is in April and the length of raining season is between 161-200 days with highest been recorded in August and September (Olasehinde, 




Figure 1: Niger State Showing Shiroro LGA

Source: Ministry of land and survey, Niger State

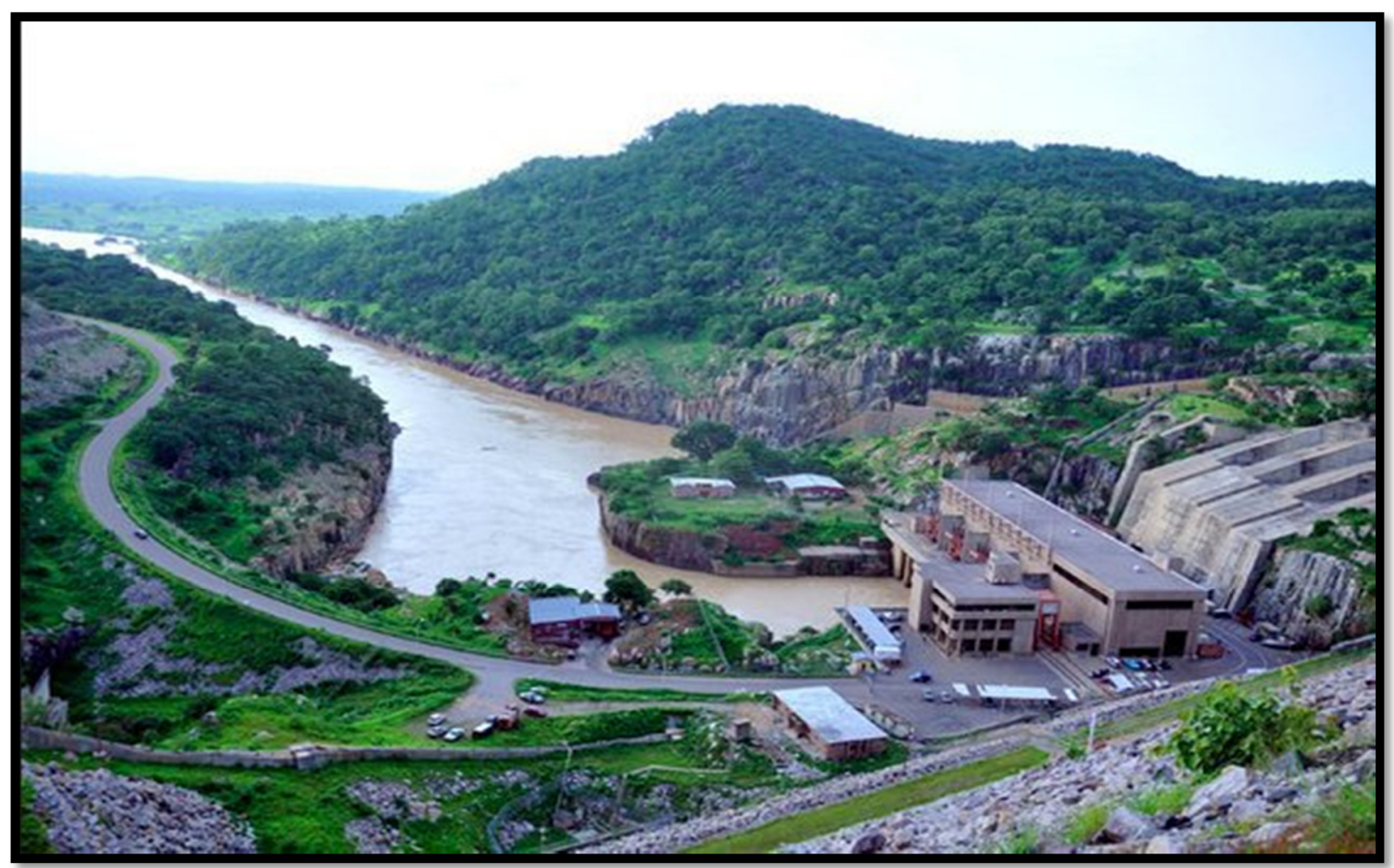

Plate 1: Shiroro Hydropower and the Downstream flow of Water Source: Insidearewa.com.ng 
IISTE

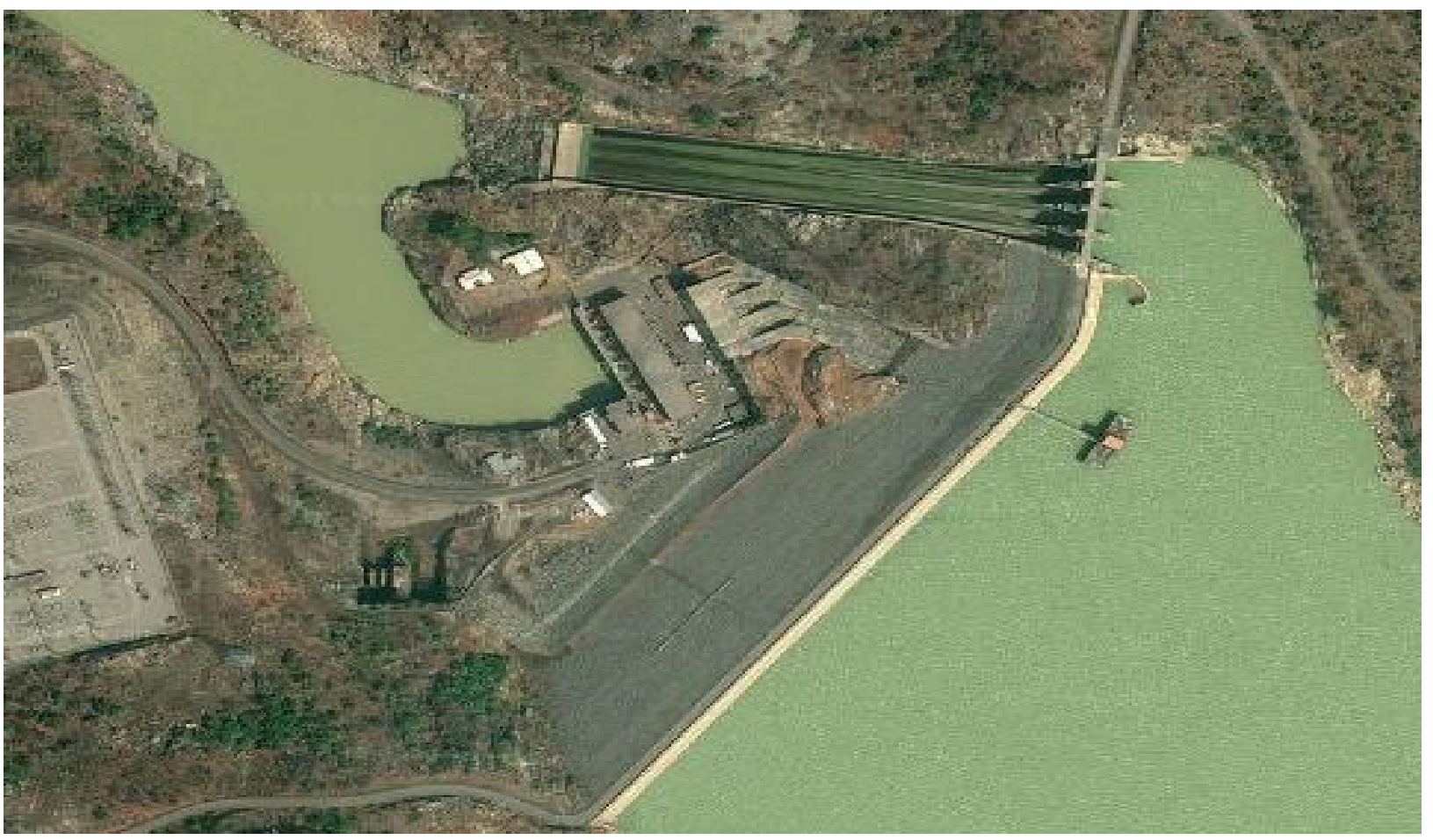

Figure 2: Satellite imagery of Shiroro Hydropower

Source: Google Earth

\subsection{MATERIALS AND METHODS}

Generally data can be collected from two sources; secondary sources and primary sources. These two sources of data (secondary and primary data) were used in this research work to quantify the environmental effect of Shiroro hydroelectric dam on the three downstream communities of Shiroro local government area. The secondary data related to this topic was collected using journals, books, articles as well as encyclopaedias among others. As primary source is a direct source used for collecting raw data, the method of primary data collection is explained below.

The data and information collected were analysed using descriptive statistics, Kruskal Wallis; with the results and findings presented in results and discussion. Furthermore, pie chart and bar chart was used as a method of displaying analyses; reasons been that they help in rapid understanding of results. In addition, Pie charts usually presented in percentages shows the proportion of respondents in each pie and bar charts are used with frequency distribution table and are vertical or horizontal bars. The height of the bars describes the proportion of the frequency (Naoum, 2013). Furthermore, descriptive and distribution Statistics of research variables and reliability test using Cronbach's alpha respectively was carried out to test the normality and internal consistencies of the constructs in the questionnaire.

The responses to the survey were input into statistical package for social science (SPSS) version 20 for windows so as to carry out statistical analysis of the data collected from the study. The SPSS software tool enables the computation of frequency, means, median, standard deviation of the data collected from the study. It also enables detailed statistical analysis such as Cronbach's alpha test to test the level of association between data.

\subsection{RESULTS AND DISCUSSIONS}

\subsection{Environmental Impacts of the Dam on the Downstream Communities}

This part of the questionnaire (i.e. section B) (see appendix 1) was analysed using factor analysis in the form of principal components analysis (PCA). Hence, the PCA was run for each category of impacts to identify the most and the least significant impacts of the dam on the downstream communities based on the responses gotten from respondents.

Table 4.4 shows the result of principal component analysis. Though, prior to performing PCA, the suitability of data for factor analysis was assessed using Kaiser-Meyer-Olkin and Bartlett's Test of Sphericity. Moreover, the correlation matrix was inspected and which revealed the presence of many coefficients of 0.3 and above. The Kaiser-Meyer-Olkin value was 0.71, exceeding the recommended value of 0.60 (Kaiser 1970, 1974) while Bartlett's Test of Sphericity was statistically significant i.e. $p=0.000$ (significant value should be 0.05 or smaller) (Bartlett, 1954); therefore supporting the factorability of the correlation matrix. 
PCA revealed that five components have Eight values exceeding 1 (Table 4.5), explaining 24.75\%, 10.72\%, $7.86 \%, 7.66 \%$ and $6.74 \%$ of the variance respectively. An examination of the scree plot (Figure 4.5 ) revealed a clear break after the nine components. Using Catell's (1966) screen test, it was decided to retain nine components as the core impacts of the hydropower dam that affect the communities most and these impacts are greenhouse gases emission, changes on invertebrates, fish and birds, changes on plankton and periphyton, depleted oxygen level, soil and environmental toxicity, changes in riparian vegetation, changes in river water cleanliness, changes to channel shape and changes in floodplains. This result support literature of environmental impacts of dam on downstream communities (see Brandt, 2000a; Cause, 2001; Church, 1995; Collier et al., 1996; Crawford, et al., 1994; Doutriaux, 2006; Jüstrich et al., 2006; Petts, 1984; Teoduru and Wernli, 2005; Valentin et al., 1995; Walker, 1979; Wildi et al., 2003, 2004).

Table 3.1: PCA of how Environmental Impact Affect Downstream Communities

\begin{tabular}{|c|c|c|c|c|c|c|c|}
\hline \multirow[t]{2}{*}{ Components } & \multicolumn{3}{|c|}{ Initial EigenValues } & \multicolumn{3}{|c|}{$\begin{array}{l}\text { Extraction Sums of Squared } \\
\text { Loadings }\end{array}$} & \multirow[t]{2}{*}{ Total } \\
\hline & Total & $\begin{array}{c}\% \text { of } \\
\text { Variance }\end{array}$ & $\begin{array}{c}\text { Cumulative } \\
\% \\
\end{array}$ & Total & $\begin{array}{c}\% \text { of } \\
\text { Variance }\end{array}$ & $\begin{array}{c}\text { Cumulative } \\
\% \\
\end{array}$ & \\
\hline $\begin{array}{l}\text { Greenhouse } \\
\text { gases emission }\end{array}$ & 3.961 & 24.754 & 24.754 & 3.961 & 24.754 & 24.754 & 3.472 \\
\hline $\begin{array}{l}\text { Changes on } \\
\text { invertebrates, } \\
\text { fish and birds }\end{array}$ & 1.714 & 10.715 & 35.469 & 1.714 & 10.715 & 35.469 & 2.235 \\
\hline $\begin{array}{lr}\text { Changes } & \text { on } \\
\text { plankton } & \text { and } \\
\text { periphyton } & \\
\end{array}$ & 1.258 & 7.863 & 43.332 & 1.258 & 7.863 & 43.332 & 1.275 \\
\hline $\begin{array}{l}\text { Depleted } \\
\text { oxygen level }\end{array}$ & 1.225 & 7.659 & 50.991 & 1.225 & 7.659 & 50.991 & 1.839 \\
\hline $\begin{array}{l}\text { Soil and } \\
\text { environmental } \\
\text { toxicity }\end{array}$ & 1.078 & 6.735 & 57.726 & 1.078 & 6.735 & 57.726 & 1.398 \\
\hline $\begin{array}{l}\text { Changes in } \\
\text { riparian } \\
\text { vegetation }\end{array}$ & .987 & 6.169 & 63.895 & & & & \\
\hline $\begin{array}{l}\text { Changes in } \\
\text { river water } \\
\text { cleanliness }\end{array}$ & .946 & 5.913 & 69.808 & & & & \\
\hline $\begin{array}{l}\text { Changes to } \\
\text { channel shape }\end{array}$ & .778 & 4.861 & 74.669 & & & & \\
\hline $\begin{array}{l}\text { Changes in } \\
\text { floodplains }\end{array}$ & .760 & 4.748 & 79.417 & & & & \\
\hline $\begin{array}{l}\text { Water sourced } \\
\text { illnesses }\end{array}$ & .670 & 4.185 & 83.602 & & & & \\
\hline $\begin{array}{l}\text { Changes in } \\
\text { seasonal and } \\
\text { annual flows }\end{array}$ & .628 & 3.923 & 87.525 & & & & \\
\hline $\begin{array}{l}\text { Changes in } \\
\text { sediment loads }\end{array}$ & .581 & 3.628 & 91.153 & & & & \\
\hline $\begin{array}{l}\text { Changes in } \\
\text { water } \\
\text { temperature }\end{array}$ & .454 & 2.836 & 93.990 & & & & \\
\hline $\begin{array}{ll}\text { Changes } & \text { on } \\
\text { territorial } & \\
\text { biological } & \\
\text { systems } & \\
\end{array}$ & .408 & 2.549 & 96.539 & & & & \\
\hline $\begin{array}{l}\text { Changes in } \\
\text { mammals }\end{array}$ & .356 & 2.225 & 98.764 & & & & \\
\hline $\begin{array}{l}\text { Salinization of } \\
\text { water }\end{array}$ & .198 & 1.236 & 100.000 & & & & \\
\hline
\end{tabular}

Source: Field Survey, 2014. 


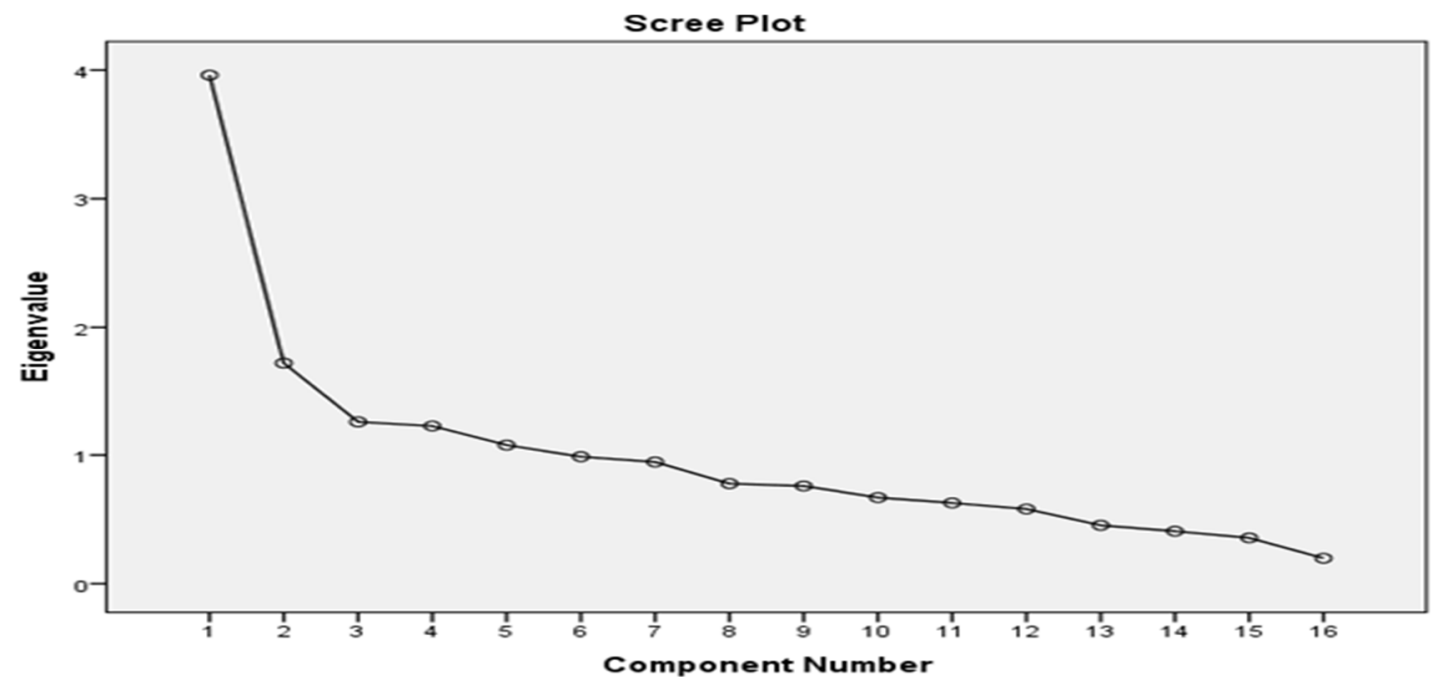

Figure 3.1: Scree Plot of Environmental Impacts of the Dam on Downstream Communities. Source: Field Survey, 2014.

\subsection{Control Techniques to Lessen the Severity of the Effects of the Dam on Downstream Communities.}

Similarly this part of the questionnaire was also analysed using factor analysis in the form of principal components analysis (PCA). The PCA was run for each control techniques so as to identify the most (core) and the least significant control techniques to lessen the severity of the effects of the dam on downstream communities.

Table 4.5 indicates the result of principal component analysis for control techniques to lessen the severity of the effects of the dam on downstream communities. Moreover, before conducting PCA, the suitability of data for factor analysis was assessed using Kaiser-Meyer-Olkin and Bartlett's Test of Sphericity. Additionally, the correlation matrix was inspected and which revealed the presence of many coefficients of .3 and above. The KaiserMeyer-Olkin value was .69, exceeding the recommended value of .60 (Kaiser 1970, 1974) while Bartlett's Test of Sphericity was statistically significant i.e. $\mathrm{p}=.000$ (significant value should be .05 or smaller) (Bartlett, 1954); therefore supporting the factorability of the correlation matrix.

PCA revealed that two components have eigenvalues exceeding 1 (Table 4.6), explaining 29.74\% and 18.28\% of the variance respectively. An examination of the scree plot (Figure 4.6) revealed a clear break after the six components. Furthermore, using Catell's (1966) scree test, six components was retain as the core control techniques to lessen the severity of the effects of the dam on downstream communities and these techniques include watershed management, water pollution control, management of water releases, fishing regulation, fish hatcheries and fish passage facilities.

Table 3.2: Control Techniques to Lessen the Impact of the Dam

\begin{tabular}{|c|c|c|c|c|c|c|c|}
\hline \multirow[t]{2}{*}{ Components } & \multicolumn{3}{|c|}{ Initial Eigenvalues } & \multicolumn{3}{|c|}{$\begin{array}{c}\text { Extraction Sums of Squared } \\
\text { Loadings }\end{array}$} & \multirow[t]{2}{*}{ Total } \\
\hline & Total & $\begin{array}{c}\% \text { of } \\
\text { Variance }\end{array}$ & Cumulative $\%$ & Total & $\begin{array}{c}\text { \% of } \\
\text { Variance }\end{array}$ & Cumulative \% & \\
\hline $\begin{array}{l}\text { Watershed } \\
\text { management }\end{array}$ & 2.379 & 29.743 & 29.743 & 2.379 & 29.743 & 29.743 & 2.136 \\
\hline $\begin{array}{l}\text { Water pollution } \\
\text { control }\end{array}$ & 1.463 & 18.284 & 48.026 & 1.463 & 18.284 & 48.026 & 1.935 \\
\hline $\begin{array}{l}\text { Management of } \\
\text { water releases }\end{array}$ & .989 & 12.363 & 60.389 & & & & \\
\hline $\begin{array}{l}\text { Fishing } \\
\text { regulation }\end{array}$ & .859 & 10.741 & 71.130 & & & & \\
\hline Fish hatcheries & .704 & 8.798 & 79.928 & & & & \\
\hline $\begin{array}{l}\text { Fish passage } \\
\text { facilities }\end{array}$ & .593 & 7.412 & 87.340 & & & & \\
\hline $\begin{array}{l}\text { Compensatory } \\
\text { protected areas }\end{array}$ & .530 & 6.625 & 93.964 & & & & \\
\hline $\begin{array}{l}\text { Physical removal } \\
\text { of floating } \\
\text { aquatic weeds }\end{array}$ & .483 & 6.036 & 100.000 & & & & \\
\hline
\end{tabular}

Source: Field Survey, 2014. 


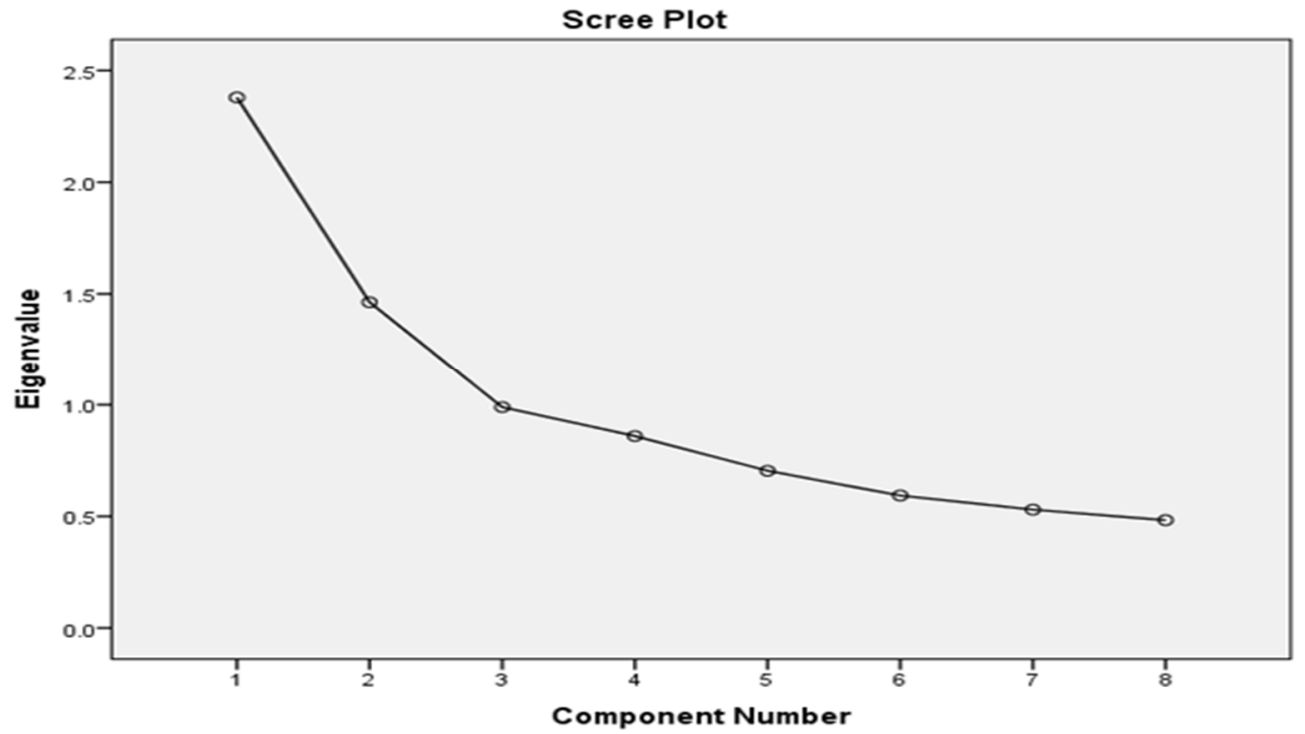

Figure 3.2: Scree Plot for Control Techniques to Lessen the Severity of the Effects of the Dam on Downstream Communities

Source: Field Survey, 2014.

\subsection{Level of Environmental Management of the Dam}

Figure 4.7 shows that $44.4 \%$ (87) of the respondents indicated that the level of environmental management of the dam is poor, $26.5 \%$ (52) indicated that they don't know, $25.5 \%$ (50) of the respondents say the environmental management level is very poor while $3.6 \%$ (7) believe the level of environmental management is good. No respondent indicatedvery good.' This shows that the environmental management level is poor.

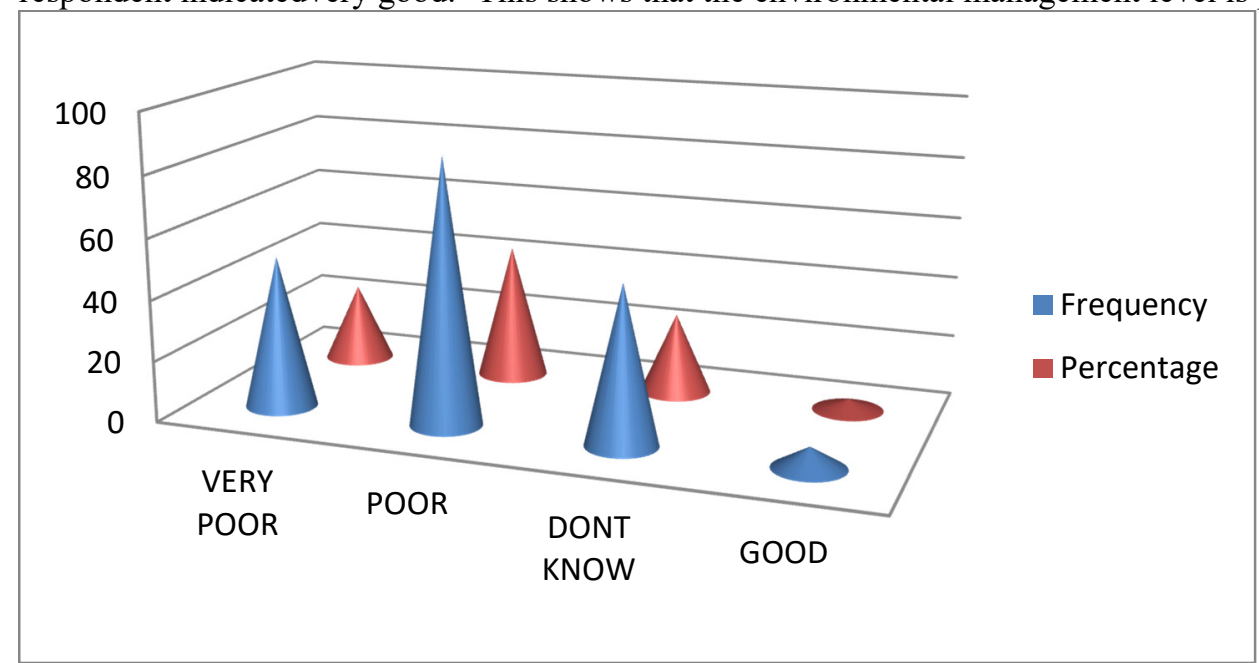

Figure 3.3: Level of Environmental Management of the Dam

Source: Field Survey, 2014

\subsection{Hypothesis Testing}

The research hypothesis was tested using Kruskal-Walis test so as to determine if there is statistically significant difference of the environmental impacts experienced by the three communities under study. Table 4.7 presents the result. 
Table 3.4: Kruskal-Wallis Test Statistics

\begin{tabular}{|l|l|l|l|}
\hline Environmental Impact & Chi-Square & Df & Asymp. Sig. \\
\hline Changes in Daily Flow & 1.213 & 4 & .876 \\
\hline Changes In Seasonal And Annual Flows & 4.537 & 4 & .338 \\
\hline Salinization Of Water & 12.611 & 4 & .013 \\
\hline Changes In Water Temperature & 2.143 & 4 & .709 \\
\hline Depleted Oxygen Level & 8.445 & 4 & .077 \\
\hline Changes In Sediment Loads & 6.329 & 4 & .176 \\
\hline Changes In River Water Cleanliness & 16.452 & 4 & .002 \\
\hline Changes To Channel Shape & 18.948 & 4 & .001 \\
\hline Changes In Floodplains & 13.955 & 4 & .007 \\
\hline Soil And Environmental Toxicity & 14.565 & 4 & .006 \\
\hline Changes In Riparian Vegetation & 12.722 & 4 & .013 \\
\hline Changes On Plankton And Periphyton & 4.005 & 4 & .405 \\
\hline Changes On Invertebrates, Fish And Birds & 19.954 & 4 & .001 \\
\hline Changes In Mammals & 17.294 & 4 & .002 \\
\hline Changes On Territorial Biological Systems & 25.005 & 4 & .000 \\
\hline Greenhouse Gases Emission & 13.038 & 4 & .011 \\
\hline Water Sourced Illnesses & 12.400 & 4 & .015 \\
\hline
\end{tabular}

\section{Source: Field Survey, 2014.}

The result in Table 4.6 shows that majority of the environmental impacts affecting the communities under study are significantly statistically different; these impacts are salinization of water, changes in river water cleanliness, changes in floodplains, soil and environmental toxicity, changes in riparian vegetation, changes on invertebrates, fish and birds, changes in mammals, changes on territorial biological systems, greenhouse gases emission and water sourced illnesses. However, other environmental impacts such as changes in daily flow, changes in water temperature, depleted oxygen level, changes in sediment loads, changes on plankton and periphyton shows that there are statistically not different among the communities under study.

Hence, the null hypothesis 'there is no statistically significance difference among the three communities under study' is rejected and the alternate hypothesis 'there is statistically significance difference among the three communities under study' is accepted.

\subsection{CONCLUSION}

Dams and the environment interrelate with a high degree of complexity. Responses of river ecosystems to dams are multiple, varied and complex. They depend not only on the dam structure and its operation but also local sediment supplies, geomorphic constraints, climate, and the key attributes of the local biota. Additionally, Dams cause changes in abiotic steering variables related to hydrology, geomorphology and water quality and these changes impact on the biotic components (including people) of river ecosystems. The impacts of a dam may occur a great distance from where it is built. The environmental consequences of impoundment cannot be considered in isolation but must be considered within the context of the whole river ecosystem including the coastal zone. Despite the research that has been conducted to date, it is in many cases impossible to predict, even with site specific studies, what the precise impacts of a dam will be. This is particularly true of the second (and third) order impacts that may not occur until many years, maybe even millennia, after dam closure.

Furthermore, assessments of dam projects in Shiroro have illustrated problems for effective environmental protection and maintenance of livelihoods for affected peoples. A general conclusion can be made that suggests, in addition to more holistic cost-benefit analyses, dam developers and financiers need to establish more accountability and transparency. Clear mechanisms also need to be in place to allow affected individuals and stakeholders an active voice in decisions for projects, including both dam construction and removal. In addition, the implementation of more thorough cost-benefit analyses conducted at the onset of project development could improve protection of the environment and local livelihoods. Cost-benefit analyses should accurately reflect costs of dam projects throughout a dam's entire lifespan, as well as include multiple spatial and temporal contexts.

Subsequently the actual nature of developing large-scale hydroelectric dams involves the almost irreversible action of changing landscapes and their respective ecosystems, it can be considered that there is almost no turning back once the dams and respective reservoirs have been filled. Hence, comparing this to the decommissioning of a gas power plant, the immense need for funds to effectuate such transformations becomes seeming and thus puts a huge question mark over the benefits of hydro technology. Furthermore, the use of more manageable renewable resources such as wind, solar and photovoltaic technologies can be easily decommissioned in comparison with hydropower and have less effect on the environment, so in the absolute need for using hydropower if these technologies were not adequate in meeting energy demands, turning to hydropower should be a last resort option. 


\section{REFERENCES}

Ajibode and Wright (1985). Reservoir sedimentation: impact, extent and mitigation. World Bank technical Paper 71

Andrews, E.D., (1986). Downstream effects of Flaming Gorge Reservoir on the Green River, Colorado and Utah. Geological Society of America Bulletin 97, 1012-1023

Aribisala, J. O. and Sule, B. F. (1998). Seasonal operation of a Reservoir Hydropower system, Technical Transactions, Nigerian Society of Engineers, NSE, Vol. 33 No 2: 1-14

Arthington, A.H., et al., (2010). Preserving the biodiversity and ecological services of rivers: new challenges and research opportunities. Freshwater Biology, 55 (1), 1-16.

Barrow C.J (1995). Impacts of large dams' in Developing the Environment, pp.226-233, Longman, Singapore

Bartlett, M. S (1954). A note on the multiplying factors for various chi square approximations. Journal of Royal statistical society, 16 (series B), 296-298

Baskaya, S; Baskaya, E; And Sari, A. (2011), The Principal Negative Environmental Impacts Of Small Hydropower Plants In Turkey. African Journal of Agricultural Research 6(14):3384-3290.

Berkermman, M. (1995), How Would You Like Your Sustainability Sir? Weak or Strong?A Reply to My Critics; Environmental Values. 4(2): 167-179

Bell. M. C., DeLacy A. C. and Paulik G. J. (1967). A Compendium on the Success of Passage of Small fish through Turbines, Report on Contract DA-35-026-CIVENG-66-16 to North Pacific Division,U.S. Army Corps of Engineers.

Berga, L.; Buil, J.M.; Bofill, E.; De Cea, J.C.; Garcia Perez, J.A.; Manueco, G.; Polimon, J.; Soriano, A. and Yague, J. (2006). Dams and reservoirs, societies and environment in the 21 st century.In Proceedings of the International Symposium on Dams in Societies of the 21st Century, Barcelona, Spain, 18 June 2006. London: Taylor and Francis Group.

Borland, W. M., and C. R. Miller (1960).Sediment problems of the lower Colorado River, Proc. Am. Soc. Civ. Eng. J. Hydraul.Div., 86(4), 61-87.

Born, S.M., et al., (1998). Socioeconomic and institutional dimensions of dam removals: the Wisconsin experience. Environmental Management, 22 (3), 359-370.

Bouck, G. R. (1980). “Subduing the Sea’s Onslaught”. South, July. In McCully 1996.

Brandt, S. A. (2000a). Classification of geomorphological effects downstream of dams, Catena, 40, 375-401

Brandt, S.A. (2000), A Tale of Two World Bank Financed Dam Projects In The Horn Of Africa. World Commission on Dams: Dams and Cultural Heritage Management. Final Report, August 2000. Working Paper Submitted To WCD By Steven, A. Brandt And Fekri Hassan. World Commission on Dams Secretariat P.O. Box 16002 Vlaeberg, Cape Town 8018, South Africa, http//www.Dams.Org

Bratrich, C., Truffer, B., Jorde, L.,Markard, J.,Meier,W., Peter, A., Schneider,M. andWehrli, B. (2004). Green hydropower: a new assessment procedure for river management. River Research and Applications, 20, 865882.

Brisbane Declaration, 2007. The Brisbane Declaration: environmental flows are essential for freshwater ecosystem health and human well-being [online]. 10th International River symposium and International Environmental Flows conference, Brisbane, Australia. Available from: http://www.eflownet.org/download_documents/brisbane-declaration-english.pdf [Accessed 13 September 2014].

Bryman, A. (2012), Social Research Methods, 4th Ed., Oxford University Press, New York

Bunn, S.E. and Arthington, A.H., (2002). Basic principles and ecological consequences of altered flow regimes for aquatic biodiversity. Environmental Management, 30 (4), 492-507.

BWG (2002).Sicherheit der Stauanlagen.Richtlinie.BundesamtfürWasser und Geologie, Biel, 119 pp. 